\section{REMARKABLE KARSTOLOGISTS OF VRHNIKA (SLOVENIA)}

Address of academician Branko Stanovnik at the unveiling the monument to karstologists from Vrhnika Ivan Michler, France Habe and Peter Habič on December 13, 2008

Respected Mrs. President of the Vrhnika Museum Society, respected Mr. Mayor, dear relatives, dear inhabitants of Vrhnika, respected guests, dear friends

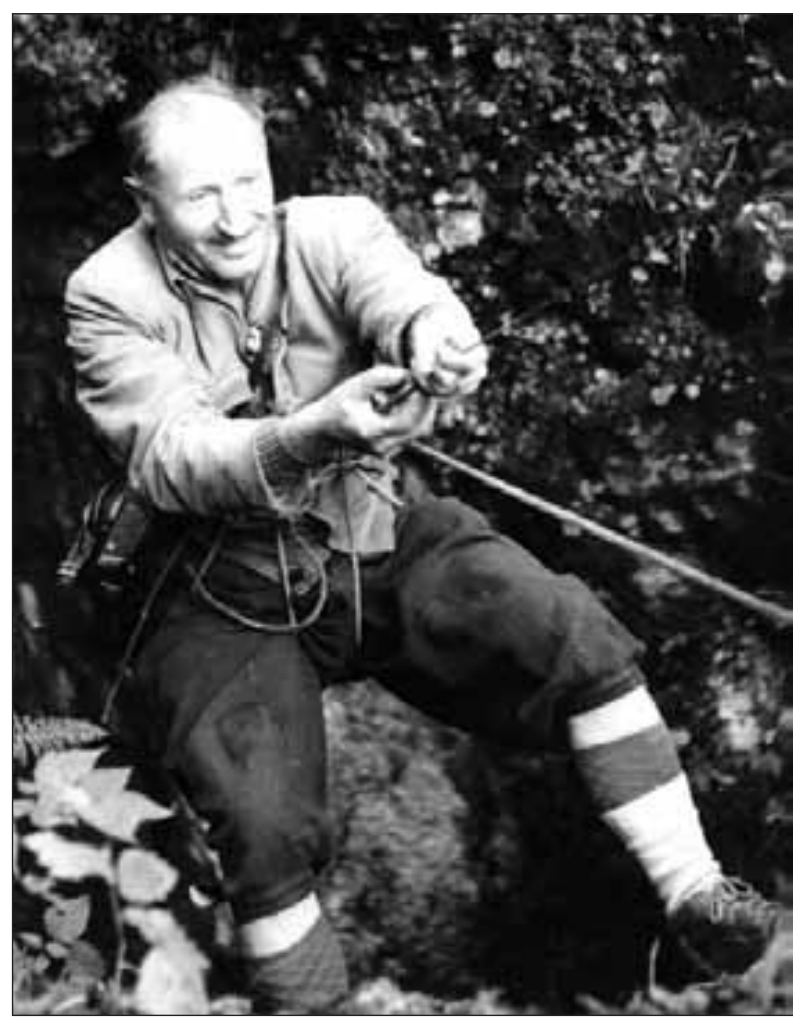

France Habe in years 1960 - 1965 (Photo: M. Orožen Adamič).

France Habe v letih 1960 - 1965 (Foto: M. Orožen Adamič).

Today we gathered in this majestic amphitheatre of Veliki Močilnik, there where karst waters leave the underground for the last time, with a view to pay homage to memory and to unveil the monument dedicated to three men of merit from Vrhnika, Ivan Michler, France Habe and Peter Habič, to three generations of karstologists and speleologists; their work left an indelible trace at first in Slovene and later in the international speleology. In the last days even the underground karst world concentrated all its power and broke out with extremely high waters as in wish to join the today's solemnity and to thank those men for their efforts at exploring the mysteries of the underground Ljubljanica.

\section{ZNAMENITI VRHNIŠKI KRASOSLOVCI}

Nagovor akademika Branka Stanovnika ob odkritju spomenika vrhniškim krasoslovcem Ivanu Michlerju, Francetu Habetu in Petru Habiču 13. decembra, 2008.

Spoštovana gospa predsednica Vrhniškega muzejskega društva, spoštovani gospod župan, dragi sorodniki, dragi Vrhničani, spoštovani gostje, dragi prijatelji,

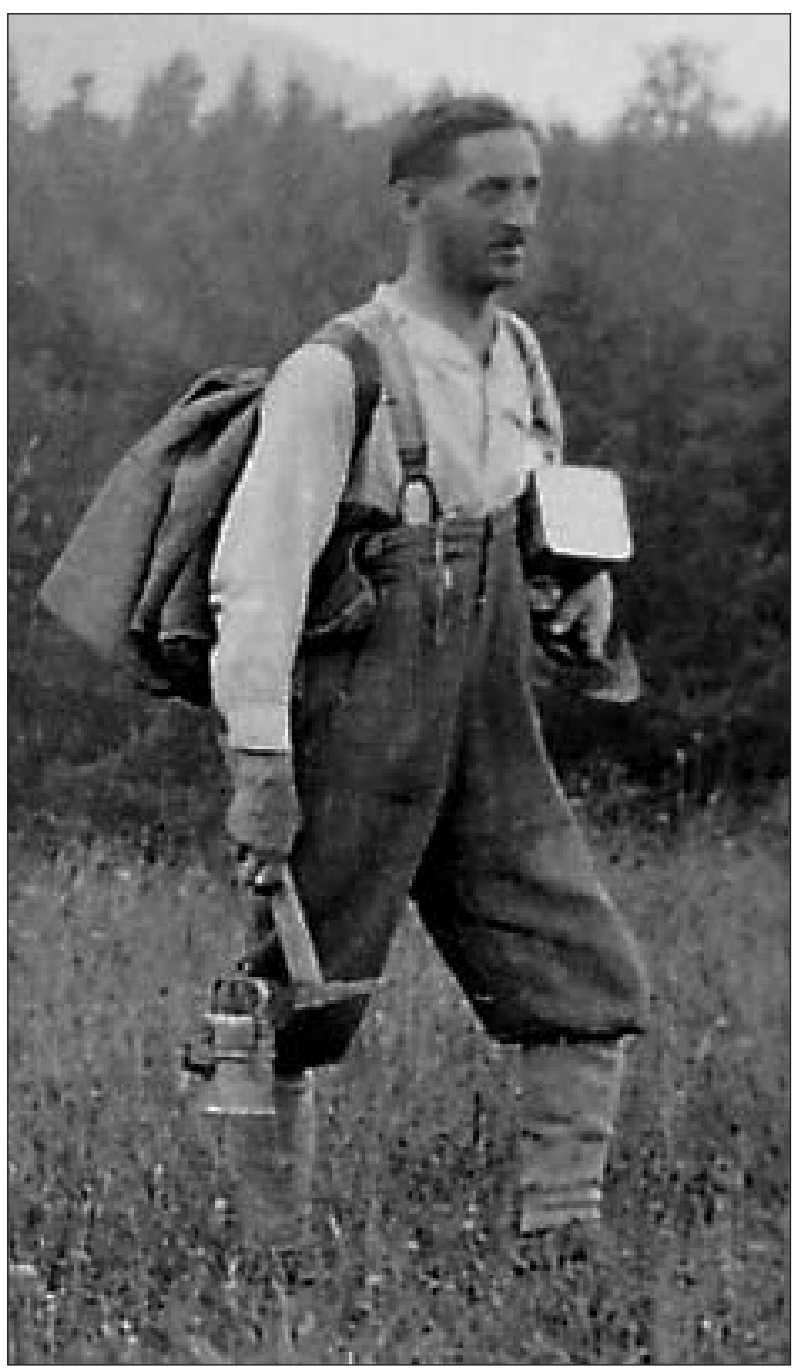

Ivan Michler (Photo / Foto: F. Bar)

Danes smo se zbrali na tem mestu v prelepem amfiteatru Velikega Močilnika, ko kraške vode zadnjikrat zapustijo podzemlje, $\mathrm{z}$ namenom, da počastimo spomin in odkrijemo spomenik trem zaslužnim vrhniškim možem Ivanu Michlerju, Francetu Habetu in Petru Habiču, trem generacijam krasoslovcev, speleologov, ki so s svojim 
Ivan Michler, France Habe and Peter Habič belonged to three generations and they devoted practically the whole $20^{\text {th }}$ century to exploration of the Slovene karst world. Ivan Michler has started to explore caves in the year 1911 already. During the First World War together with Pavel Kunaver they explored karst for the need of Austrian army in the rear of the Soča front. After the 1st World War he continued to work within the Society for the Exploration of Caves together with Albin Seliškar, Alfred Šerko, Roman Kenk, Franci Bar and already with Egon Pretner and France Habe.

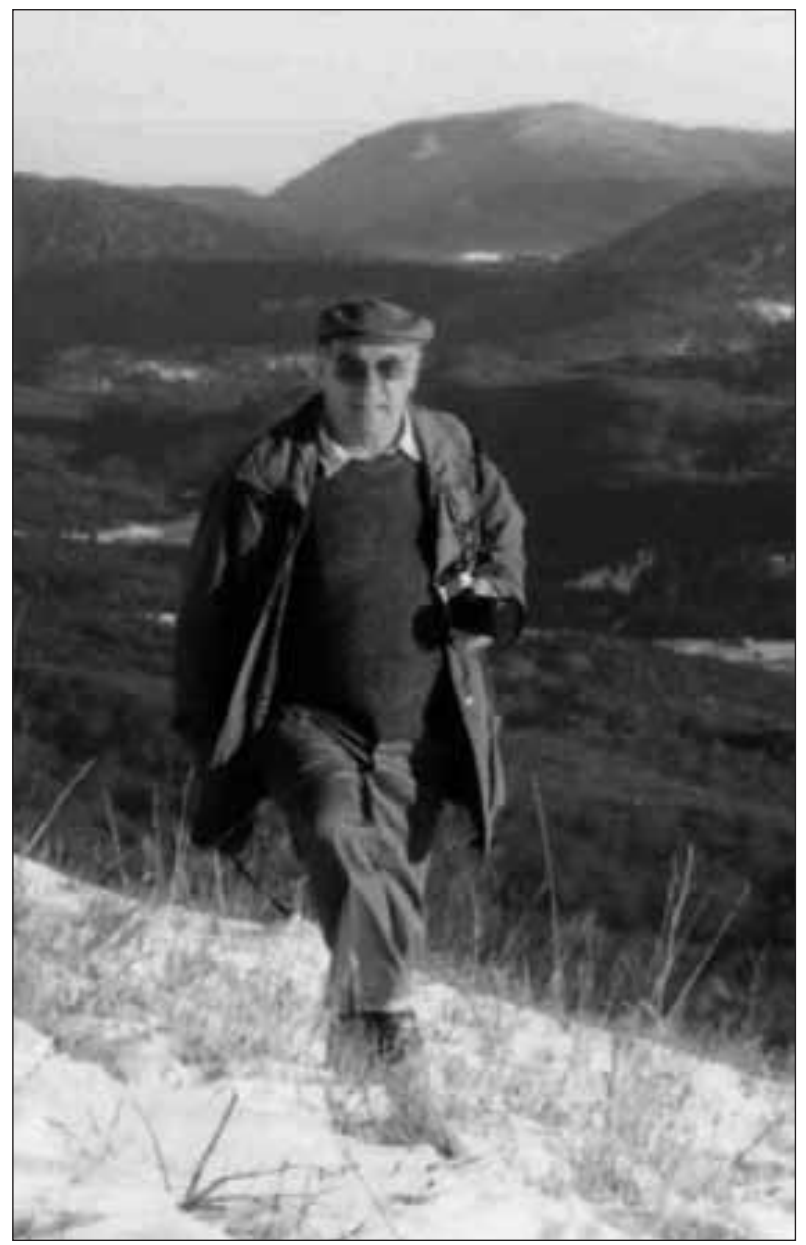

Dr. Peter Habič on Slivnica in November, 1998 (Photo: S. Habič).

Dr. Peter Habič na Slivnici v novembru 1998 (Foto: S. Habič).

As the border with Italy was near, their explorations were limited to the river basin of the underground Ljubljanica between Vrhnika and Logatec, Planinsko polje and Loška dolina. Remembering these days Michler said: "Sunday after Sunday we came back home dirty, muddy and tired. People watched us with pity. We did not hold a grudge against them as they did not know the duties that we performed because of our delom vtisnili najprej slovenski, pozneje pa tudi svetovni speleologiji neizbrisni pečat. Tudi podzemni kraški svet je $\mathrm{v}$ teh dneh zbral vse svoje moči in $\mathrm{z}$ ekstremno visokimi vodami izbruhnil na dan, kot da bi se hotel pridružiti današnji slovesnoti in se zahvaliti tem možem za njihov trud pri odkrivanju skrivnosti podzemne Ljubljanice.

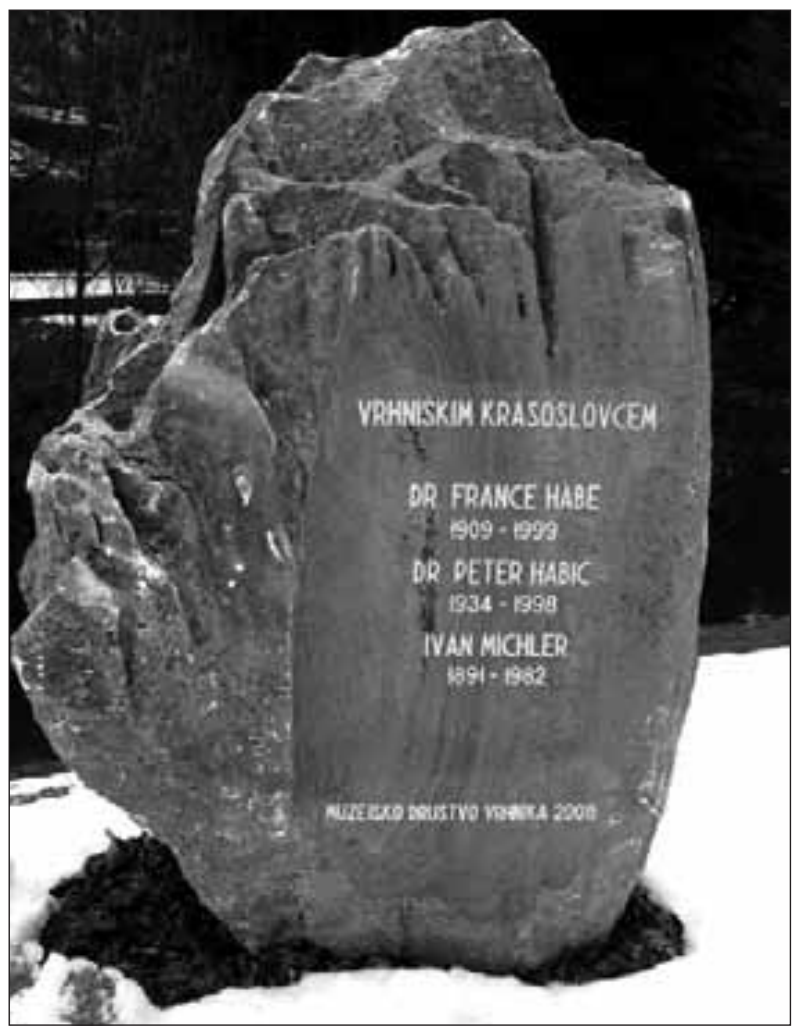

Monument erected to the karstologists of Vrhnika. (Photo: A Kranjc).

Spomenik znamenitim vrhniškim krasoslovcem $v$ Močilniku (Foto: A Kranjc)

Ivan Michler, France Habé in Peter Habič so pripadali trem generacijam, ki so praktično celo 20 . stoletje posvetili raziskovanju slovenskega kraškega sveta. Ivan Michler je začel raziskovati jame že leta 1911. Med 1. svetovno vojsko sta skupaj s Pavlom Kunaverjem raziskovala kraški svet za potrebe avstrijske vojske v zaledju soške fronte. Po 1 . svetovni vojski je delo v okviru Društva za raziskovanje jam nadaljeval skupaj z Albinom Seliškarjem, Alfredom Šerkom, Romanom Kenkom, Francijem Barom, pa tudi že z Egonom Pretnerjem in Francetom Habetom. Zaradi bližnje meje z Italijo, je bilo njihovo raziskovanje omejeno na porečje podzemne Ljubljanice med Vrhniko in Logatcem, Planinsko polje in Loško dolino. Ob spominu na tiste čase pravi Michler: "Nedeljo za nedeljo smo se vračali umazani, blatni in trudni domov. Ljudje so nas pomilovalno opazovali. 
love for nature and comprehension for our beautiful homeland $"$.

After the Second World War the border changed. Slovenia got back Primorska and explorations expanded to the underground around Pivka and Postojna, to Planinska jama, Trnovski gozd and Škocjanske jame. At Postojna Slovene Academy of Sciences and Arts founded the Institute of Karst Research; France Habe and Peter Habič took an active part and led many projects and the Institute developed into scientific research institution taking care for researches related to hydrography, hydrology, geomorphology, underground water tracing, speleological map of Slovenia etc. The Institute participates with many related institutions all over the world from USA to China. Peter Habič was several years its head, he was the main organizer of many international congresses and symposia, for many years member of the editorial board, co-editor and editor-in-chief of the scientific journal Acta carsologica, co-published by the Slovene Academy of Sciences and Arts and now one of the leading international journals in the sphere of karstology. In the global view Slovene speleology is esteemed so much that many Slovene professional terms are accepted in international languages, not only in English, German and French but also in Chinese.

But, of course, serious scientific work constantly lacks money. Already between the two wars Michler has written: "Society is poor. If there are not some gentlemen at Vrhnika with lot of sense for this serious and necessary work the Society could not achieve its programme even in a smallest extent. I am sorry to say, in higher spheres there is no understanding ..."

Here it comes to my mind the sentence of a Roman philosopher Seneca who said: "If a man does not know where he sails even a fair wind does not help."

The second one I saw many years ago at visiting Sweden at home of Dag Hammerskjöld, the then secretary general of the United nations, above his writing table in his working study: "Only the one who gazes on the remote horizons will find the right way."

These three men to whom the today's monument is dedicated, have in spite of different winds, political, ideological, economical, blowing from different directions and frequently changing orientation, men who survived two world wars and civil war with all the consequences, living in small, narrow, frequently blurred Slovene circumstances known how to find and preserve the right direction and with vision, creativity, perseverance and upright personal posture from modest beginnings helped to develop the science on karst and rising it on the international level.

The inhabitants of Vrhnika and with us all the Slovenes, we have a right to be proud of these three men
Nismo jim zamerili, saj niso poznali nalog, ki smo si jih naložili iz ljubezni do narave in spoznavanja naše prelepe domače zemlje."

Po 2. svetovni vojni je se meja spremenila. Slovenija je dobila nazaj Primorsko in raziskave so se razširile na pivško in postojnsko podzemlje, Planinsko jamo, Trnovski gozd in Škocjanske jame. Pri Slovenski akademiji znanosti in umetnosti je bil ustanovljen Institut za raziskovanje krasa s sedežem v Postojni, kjer sta aktivno sodelovala France Habe in Peter Habič in vodila mnoge projekte, tako da se je Institut razvil v pravo znanstveno raziskovalno ustanovo, ki skrbi za raziskave na področju hidrografije, hidrologije, geomorfologije, sledenju podzemnih voda, izdelavi Speleološke karte Slovenije, itd. Institut sodeluje $\mathrm{z}$ mnogimi sorodnimi ustanovami po svetu od ZDA do Kitajske. Peter Habič je bil tudi več let direktor Instituta, glavni organizator mnogih mednarodnih kongresov in simpozijev, dolga leta član uredniškega odbora, sourednik in glavni urednik znanstvenega časopisa Acta Carsologica, ki ga soizdaja Slovenska akademija znanosti in umetosti in je vodilni svetovni časopis na področju krasoslovja. Slovenska speleologija je v svetovnem merilu tako zelo cenjena, da je mnogo slovenskih strokovnih términov, prešlo $\mathrm{v}$ vse svetovne jezike, ne samo $\mathrm{v}$ angleščino, nemščino in francoščino, ampak tudi v kitajščino.

Seveda pa je za resno znanstveno delo vedno premalo denarja. Že Michler je med obema vojnama zapisal: "Društvo je siromašno. Ako bi na Vrhniki ne bilo nekaj gospodov, ki imajo smisel za to resno in potrebno delo, bi društvo ne moglo izvesti svojega programa niti v mali meri. Na višjih mestih žalibog ni umevanja ..."

$\mathrm{Ob}$ tem mi prihaja na misel izrek rimskega filozofa Seneke, ki je rekel: „Če človek ne ve kam plove, mu tudi dober veter $v$ jadrih ne pomaga."

In drugi, ki sem ga pred mnogimi leti ob obisku na Švedskem na domu Daga Hammerskjölda, takratnega generalnega sekretarja Združenih narodov, videl napisanega nad pisalno mizo v njegovem delovnem kabinetu: "Samo tisti, ki ima oči uprte v daljna obzorja, bo našel pravo pot.«

Ti trije možje, ki jim danes odkrivamo ta spomenik, so kljub različnim vetrovom, političnim, ideološkim, gospodarskim, ki so pihali iz različnih smeri in pogostoma spreminjali smer, ki so preživeli dve svetovni vojni vihri in državljansko vojno $\mathrm{z}$ vsemi njenimi posledicami, v majhnih, ozkih, često zamegljenih slovenskih razmerah znali poiskati in ohraniti pravo smer in s svojo vizijo, ustvarjalnostjo, vztrajnostjo in pokončnim osebnim značajem iz skromnih začetkov pomagali razviti znanost o Krasu in jo dvigniti na svetovni nivo.

Vrhničani, in z nami vsi Slovenci, smo upravičeno ponosni na te tri velike može, ki so ponesli védenje o 
who carried the knowledge of the Slovene karst to the world; younger generations, although complaining over future, aimless and purposeless of the actual life, let take them as a shining example!

Thank you

At Močilnik near Vrhnika, December 13, 2008

The academician Prof. Dr. Branko Stanovnik slovenskem krasu v širni svet, mlajše generacije, ki pogostoma tožijo nad brezperspektivnostjo, brezsmiselnostjo in brezciljnostjo današnjega življenja, pa naj si jih postavijo za svetál zgled.

Hvala.

V Močilniku na Vrhniki, 13. decembra, 2008.

Akademik Prof. Dr. Branko Stanovnik 